ISSN 1392-3196 / e-ISSN 2335-8947

Zemdirbyste-Agriculture, vol. 101, No. 1 (2014), p. 27-34

DOI 10.13080/z-a.2014.101.004

\title{
Miscanthus biomass quality composition and methods of feedstock preparation for conversion into synthetic diesel fuel
}

\author{
Žydrè KADŽIULIENE் ${ }^{1}$, Algirdas JASINSKAS ${ }^{2}$, Remigijus ZINKEVIČIUS'², \\ Violeta MAKAREVIČIENE ${ }^{3}$, Lina ŠARŪNAITE ${ }^{1}$, Vita TILVIKIENE $\dot{E}^{1}$, Jonas ŠLEPETYS \\ ${ }^{1}$ Institute of Agriculture, Lithuanian Research Centre for Agriculture and Forestry \\ Instituto 1, Akademija, Kedainiai distr., Lithuania \\ E-mail: zkadziul@1zi.lt \\ ${ }^{2}$ Institute of Agricultural Engineering and Safety, Aleksandras Stulginskis University \\ Studentų 15A, Akademija, Kaunas distr., Lithuania \\ ${ }^{3}$ Institute of Environment and Ecology, Aleksandras Stulginskis University \\ Studentu 15A, Akademija, Kaunas distr., Lithuania
}

\begin{abstract}
When developing various technologies designed for biomass conversion into biofuels, it is important to establish the suitability of raw material of lignocellulotic, non-food plants such as Miscanthus, whose biomass has a good energy potential. Biomass productivity, quality and its suitability for processing under more northern climatic conditions are important factors to be considered. Experiments were aimed to estimate quality and technological parameters of Miscanthus growing, harvesting and processing into synthetic diesel, to evaluate chemical, physical and mechanical properties of biomass and to determine energy consumption necessary for biomass preparation for conversion into synthetic diesel. The study object was biomass of Miscanthus (Miscanthus $\times$ giganteus Greef et Deu) produced under Lithuanian and German climate conditions.

Miscanthus harvested in the autumn produced up to $9.42 \mathrm{t} \mathrm{ha}^{-1}$ dry matter (DM) yield, which was significantly higher in the treatments fertilised with a higher nitrogen rate. The content of cellulose (413-456 g kg-1 DM) and hemicellulose (204-236 g kg-1 DM) was very similar at all fertilisation levels. The highest content of lignin (117 $\mathrm{g} \mathrm{kg}^{-1} \mathrm{DM}$ ) was established in the treatments fertilised with $120 \mathrm{~kg} \mathrm{ha}^{-1} \mathrm{~N}$. The spring-harvested Miscanthus biomass had significantly lower moisture content and the yield was significantly lower, too. While preparing the biomass as feedstock for synthetic diesel the greatest reduction in moisture content (to $8.59 \pm 1.38 \%$ ) occurred when Miscanthus biomass was chopped, pre-dried and milled, and particles larger than $2 \mathrm{~mm}$ accounted for the largest share. The energy use for chopping of autumn-harvested biomass was lower and chopping efficiency was higher compared with the spring-harvested biomass. The composition of major components of synthetic fuel from Miscanthus biomass was very similar to that of mineral diesel.
\end{abstract}

Key words: biomass, harvesting time, Miscanthus, physico-mechanical properties, synthetic diesel.

\section{Introduction}

Nowadays biodiesel is regarded as an environmentally friendly fuel whose production is expected to grow in the near future, especially from lignocellulosic crops such as Miscanthus or other similar new energy crops which are not associated with food crops and which are considered to have energetic, economic and environmental advantages over food crops (Janaun, Ellis, 2010; Reijnders, 2010). Different biofuels are generated from diverse renewable resources and biodiesel is one of the most important transport fuels that can be obtained from biomass using different conversion processes (Demirbas, 2009; Cheng, Timilsina, 2011). Gasification of lignocellulosic biomass provides a way to produced different liquid fuels (Simmons, 2012), therefore biodiesel can be produced from all types of biomass that can be gasified, herewith technologies for converting biomass to biodiesel also are at various stages of development (Yousuf, 2012). When developing technologies for biomass conversion, several important aspects such as biomass feedstock potential and quality should be considered. Superior raw material is that which comes from crops which produce higher yields than food crops and have other advantages such as possibility to produce considerable quantity of biomass in less fertile soils (Carriquiry et al., 2011). Studies were done on the biomass of various energy plants and assessment of biomass suitability for processing was carried out. Miscanthus $\times$ giganteus is one of the benefited crops relevant as biomass feedstock especially in warmer and moderate climate zone countries (Clifton-Brown et al., 
2004; Hastings et al., 2009; Anderson et al., 2011; Zub et al., 2011). Despite poor overwintering in the first year, Miscanthus has been indicated as an energy crop, which can be grown almost in all Europe (Clifton-Brown, Lewandowski, 2002; Clifton-Brown et al., 2004) and some experiments conducted in more northern countries concluded the same (Jezowski et al., 2011; Kryževičienè et al., 2011).

There are various considerations to improve the biomass quality of the recycling process to obtain a higher total energy. Lewandowski and Heinz (2003) reported that harvesting early in spring is recommended for Miscanthus for less moisture content. Harvesting time is important also for other quality composition characteristics (Lewandowki, Heinz, 2003; Hodgson et al., 2011; Zub et al., 2011). Morphological and mechanical properties, composition of feedstock at harvesting affect not only dry matter yield, but also the state of feedstock for subsequent conversion process and influence total energy efficiency (Kaack, Schwarz, 2001; Kaack et al., 2003; Mani et al., 2006; Igathinathane et al., 2008). Johnson et al. (2012) indicated that $M$. $\times$ gigantheus cutting process needs to be investigated in detail, which would help in developing more efficient harvesting and biomass particle size reduction equipment required for the introduction of $M . \times$ gigantheus as a bioenergy crop. Due to biomass processing technology imperfections, not all biomass is consumed, therefore in order to make the best use, it is necessary to look for ways to improve biomass feedstock preparation for processing (Robbins et al., 2012).

The aim of this study was to evaluate Miscanthus growing and harvesting and its biomass quality- technological parameters such as chemical and physico-mechanical characteristics (chaff humidity, bulk density and fineness) as well as biomass conversion into synthetic diesel.

\section{Materials and methods}

The object of this study was biomass of Miscanthus (Miscanthus $\times$ giganteus Greef et Deu) produced under Lithuanian climate conditions and German climate conditions (in the demonstrational department of the company “Alphakat GmbH”, Germany), as a feedstock for the production of synthetic diesel. The Miscanthus biomass as feedstock for conversion into energy produced in Lithuania was analysed in more detail. The trials have been conducted since 2007 at Lithuanian Institute of Agriculture (currently - Lithuanian Research Centre for Agriculture and Forestry) in Dotnuva, Kèdainiai district $\left(55^{\circ} 24^{\prime} \mathrm{N}, 23^{\circ} 52^{\prime} \mathrm{E}\right)$, in a reclaimed river bed territory. The soil is light, sand on sand with a small stone and gravel admixture, Eutri-Cambic Arenosol $(A R b-e u)$. Nitrogen $(\mathrm{N})$ fertilisation at three rates $(0,60$ and $120 \mathrm{~kg} \mathrm{ha}^{-1}$ ) was applied in spring from the second growth season onward. The biomass was harvested once a year - either in autumn (autumn harvesting) or spring (spring harvesting). To estimate biomass yield, the plants were cut and fresh mass was immediately weighed. To calculate dry matter (DM) yield of biomass, 5-6 stems were taken from each treatment replication and chopped, the mass was weighed and dried at $+105^{\circ} \mathrm{C}$ to a constant weight, and weighed again. Chemical analyses were done on a composite chopped mass samples taken from three replications then dried at $+65^{\circ} \mathrm{C}$ and ground in a cyclonic mill with $1 \mathrm{~mm}$ sieve. The samples were subjected to the fibre component analyses: acid detergent fibre (ADF) and neutral detergent fibre (NDF) and acid detergent lignin (ADL) using a cell wall detergent fractionation method according to van Soest (Faithfull, 2002). The content of cell wall structural carbohydrates hemicellulose and cellulose was calculated as the following differences: cellulose $=\mathrm{ADF}-\mathrm{ADL}$ and hemicellulose $=\mathrm{NDF}-$ ADF (Hindrichsen et al., 2006).

For the assessment of Miscanthus biomass physico-mechanical features for synthetic diesel and the energy consumption for preparation of biomass for production, the following treatments were used: $1^{\text {st }}-$ the biomass grown and prepared for the production of diesel in Germany (the biomass was grown in Germany, growing conditions were similar to those of the $2^{\text {nd }}$ treatment, biomass was harvested in autumn and chopped with a forage harvester-thresher "Maral 125" ("Fortshritt", Germany); $2^{\text {nd }}$ - the biomass grown at the Lithuanian Research Centre for Agriculture and Forestry and fertilised at $60 \mathrm{~kg} \mathrm{ha}^{-1} \mathrm{~N}$ harvested in autumn and chopped with a forage harvesterthresher "Maral 125"; $3^{\text {rd }}$ - the biomass prepared in the same way as $2^{\text {nd }}$ treatment and later this feedstock material was dried to $8 \%$ humidity; $4^{\text {th }}$ - the biomass prepared in the same way as in $3^{\text {rd }}$ treatment and milled with a hammer disintegrator "Retsch SM 200" ("Retsch", Germany); $5^{\text {th }}$ - the biomass from the Lithuanian Research Centre for Agriculture and Forestry was harvested in spring and chopped with a forage harvester-thresher "Maral 125". For the calculation of the chaff humidity the standard methodology was used (Jasinskas, Zvicevičius, 2008). The thickness of the chaff was determined by the weighing method (Jasinskas et al., 2012).

The energy consumption, necessary for chopping of Miscanthus stems, was determined by calculating the loaded and non-loaded energy outlay $(\mathrm{kWh})$ of the disintegrator's electric motor. A portable three-phase power quality analyzer "Power Q Plus" ("Metrel", Slovenia) was used for determination of energy consumption ( $\mathrm{kWh}$ ) of the disintegrator's electric motor. Cut stems samples weighing 1.5, 3 and $4.5 \mathrm{~kg}$ were fed into the chopper machine. The dried and chopped samples of the raw material were fed into the grindingmill by 25,50 and $75 \mathrm{~g}$ samples. The disintegrator working efficiency was measured using a stopwatch by determining the mass quantity of supply and duration of mass chopping.

Dry biomass of Miscanthus in Germany ("Alphakat GmbH") was processed into synthetic fuel (liquid hydrocarbons) by applying the CPD (catalytic pressureless depolymerization) technology. Physical and chemical characteristics of the synthetic diesel were compared to those of mineral diesel and compliance with the standard requirements for biodiesel was estimated 
( $1^{\text {st }}$ treatment). During the tests we used the following methods and materials: density was determined according to the standard LST EN ISO 3675 requirements; viscosity - in accordance with BS EN ISO 3104 requirements; acid value - according to the requirements of $\mathrm{BS} E N$ 14104; iodine value - according to the requirements of BS EN 14104; water content - according to DIN EN ISO 12937 requirements; sulphur content - according to the requirements of BS EN 20846; flashpoint - according to BS EN ISO 2719 requirements; ignition temperature was defined according to the requirements of LST EN ISO 2719; limitary temperature of filtration and turbidity - by LST EN ISO 116 requirements. Fourier transformation infrared (FTIR) spectroscopy analysis was performed and infrared spectrums were marked by infrared radiation spectrometer FTIR Spectrum RX I (“Arcoptix", Switzerland).

The research results were processed using the statistical analysis software package SELEKCIJA, software ANOVA and STAT (Tarakanovas, Raudonius, 2003), and least significant difference (LSD) at significance level of $P<0.05$ was used.

\section{Results and discussion}

Morphological traits, biomass yield and chemical composition of Miscanthus. Important factors for herbaceous energy plants are DM yield and harvesting time. In our research, autumn-harvested Miscanthus produced $9.42 \mathrm{t} \mathrm{ha}^{-1}$ of DM in the $5-6^{\text {th }}$ year of growing (Table 1). The DM yield depended on the $\mathrm{N}$ fertilisation level. Significant differences were observed with the highest $\mathrm{N}_{120}$ fertiliser rate compared to lower $\mathrm{N}_{60}$ and nonfertilised during both harvesting periods. As reported in literature, Miscanthus can produce high yields with low $\mathrm{N}$ inputs (Lewandovski, Kauter, 2003). However, the harvesting timing is an important factor for DM amount of Miscanthus plants. During the winter time biomass loss ranged from $32.7 \%$ to $39.6 \%$ depending on the fertilisation level. Non-fertilised Miscanthus produced significantly lower DM yield and the loss of biomass during the winter was significantly higher compared to fertilised plants.

Table 1. Biomass moisture and dry matter yield of autumnharvested $(\mathrm{AH})$ and spring-harvested $(\mathrm{SH})$ Miscanthus

\begin{tabular}{|c|c|c|c|c|}
\hline \multirow{2}{*}{ Indicators } & \multicolumn{3}{|c|}{ Fertilisation } & \multirow{2}{*}{$\mathrm{LSD}_{05}$} \\
\hline & $\mathrm{N}_{0}$ & $\mathrm{~N}_{60}$ & $\mathrm{~N}_{120}$ & \\
\hline Dry matter $\mathrm{t} \mathrm{ha}^{-1}(\mathrm{AH})$ & 4.63 & 5.45 & 9.42 & 1.81 \\
\hline Moisture content \% (AH) & 64.5 & 66.9 & 65.3 & \\
\hline Dry matter $\mathrm{t} \mathrm{ha}^{-1}(\mathrm{SH})$ & 2.79 & 3.56 & 6.34 & 1.33 \\
\hline Moisture content \% (SH) & 32.4 & 33.4 & 37.4 & \\
\hline Loss of biomass in winter $\%$ & 39.6 & 34.7 & 32.7 & 4.31 \\
\hline
\end{tabular}

Similar trends were observed in the DM structure (Table 2). The higher $\mathrm{N}_{120}$ fertiliser rate significantly increased weight per plant and tended to increase the share of stems compared to the $\mathrm{N}_{60}$ rate and non-fertilised Miscanthus. The proportion of leaves in the autumn-harvested biomass did not depend on fertiliser rates. Percentage of stems and leaves in the total biomass dried in autumn was approximately the same as in that dried in spring. At spring harvesting, DM weight per plant was lower by 17-20 g compared to that at autumn harvesting.

Table 2. Biomass structure of Miscanthus plants at harvesting

\begin{tabular}{lcccc}
\hline \multirow{2}{*}{ Indicator } & \multicolumn{4}{c}{ Fertilisation } \\
\cline { 2 - 4 } & $\mathrm{N}_{0}$ & $\mathrm{~N}_{60}$ & $\mathrm{~N}_{120}$ & \\
\hline \multicolumn{4}{c}{ Autumn-harvested biomass } \\
\hline Weight per plant g & 41.8 & 42.1 & 49.0 & 6.34 \\
Percent of leaves & 54.5 & 47.4 & 48.7 & 5.41 \\
Percent of stems & 45.5 & 52.6 & 51.3 & 5.68 \\
\hline \multicolumn{5}{c}{ Spring-harvested biomass } \\
\hline Weight per plant g & 24.8 & 23.1 & 29.4 & 4.11 \\
Percent of leaves & 26.7 & 24.8 & 20.7 & 5.07 \\
Percent of stems & 73.3 & 75.2 & 79.3 & 2.91 \\
\hline
\end{tabular}

Chemical composition of biomass is a very important parameter showing its suitability for bioenergy and how this composition could affect biomass conversion efficiency. Miscanthus accumulated 700-785 g NDF in $\mathrm{kg}^{-1} \mathrm{DM}$ of biomass depending on the $\mathrm{N}$ fertilisation level (Table 3 ). Key polymers of biomass composition such as cellulose, hemicellulose and lignin are quality indicators showing feedstock suitability for different energy conversion pathways. The content of cellulose and hemicellulose was very similar at all fertilization levels. Lignin, a constituent of fibre, is undesirable in the biomass intended for biogas or biodiesel production. Its highest content was found in the biomass of Miscanthus fertilised with $\mathrm{N}_{120}$ rate. In this study, we investigated chemical composition of only autumn-harvested biomass as influenced by $\mathrm{N}$ fertilisation. Literature sources indicate the effect of other factors as well. At autumn harvest, the cell wall composition was very similar to that of the whole biomass at winter harvest. Thus no significant differences in lignin and polysaccharide contents were observed (Huyen et al., 2010). Hodgson et al. (2011) concluded that significant variation in cell wall composition was indentified not only between Miscanthus genotypes, but also between harvest times. An important trait is moisture content in biomass. When delaying harvest time until plants have fully senesced, moisture content may reduce from 564 to $291 \mathrm{~g} \mathrm{~kg}^{-1}$ (Lewandowski, Heinz, 2003). Variation in senescence is correlated with variation in moisture content in Miscanthus (Robson et al., 2012) and consequently optimising moisture content through harvest time and senescence is one low energy route to improved conversion process. In our case, moisture content in autumn-harvested biomass was $64.5-66.9 \%$ and in spring-harvested biomass it was $32.4-37.4 \%$ (Table 1). However, delaying of harvest time correlated not only with reduction in moisture content, but also with yield. As we noticed, previous yield losses in our experiments were more than $30 \%$. Clifton-Brown and Lewandowski 
(2002) observed that the effect of harvesting delaying and the longer period between autumn and winter harvests was greater yield losses. Therefore other possibilities to improve biomass composition have to be looked for.

Table 3. Chemical composition of the above ground biomass of autumn-harvested Miscanthus plants, $\mathrm{g} \mathrm{kg}^{-1}$ dry matter

\begin{tabular}{cccccc}
\hline \multirow{2}{*}{ Treatment } & \multicolumn{2}{c}{ Fibre } & Lignin & Cellulose & $\begin{array}{c}\text { Hemi- } \\
\text { cellulose }\end{array}$ \\
\cline { 2 - 4 } & NDF & ADF & & & 236 \\
\hline $\mathrm{N}_{0}$ & 743 & 507 & 84 & 423 & 236 \\
$\mathrm{~N}_{60}$ & 700 & 495 & 82 & 413 & 204 \\
$\mathrm{~N}_{120}$ & 785 & 573 & 117 & 456 & 212 \\
\hline $\mathrm{LSD}_{05}$ & 3.60 & 23.2 & 7.1 & 19.4 & 23.7 \\
\hline
\end{tabular}

$\mathrm{NDF}$ - neutral detergent fibre, ADF - acid detergent fibre

Physico-mechanical features of Miscanthus

biomass. The moisture of Miscanthus biomass which grew in the climatic conditions of Germany and was prepared to produce synthetic diesel was $10.98 \pm 0.18 \%$ (Fig. 1). Moisture content of Lithuania-grown Miscanthus biomass, harvested in the autumn and chopped was as high as $51.92 \pm 0.90 \%$. When the biomass harvested in autumn was chopped, dried up and milled, its moisture decreased to $8.59 \pm 1.38 \%$. Meanwhile, moisture content of Miscanthus biomass harvested in spring and chopped was $30.20 \pm 4.67 \%$, or $20 \%$ less than that of the biomass harvested in autumn and chopped.
Moisture content of Miscanthus biomass \%

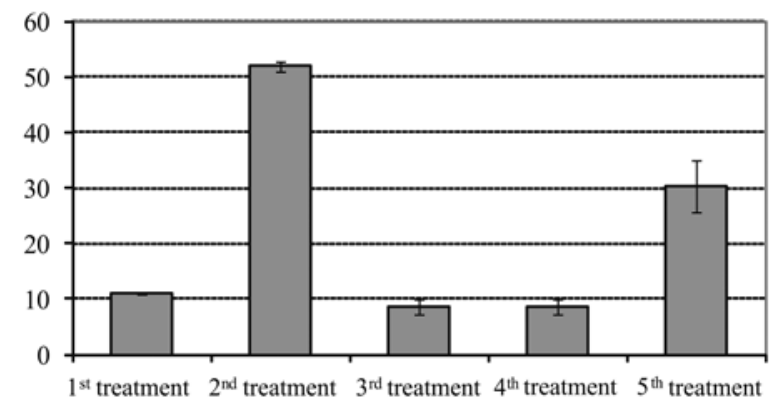

Figure 1. Moisture content of feedstock depending on the biomass preparation method

The density of Miscanthus biomass for synthetic diesel prepared in Germany was $0.184 \pm 0.016 \mathrm{~g} \mathrm{~cm}^{-3}$ and the DM density was $0.164 \pm 0.016 \mathrm{~g} \mathrm{~cm}^{-3}$ (Table 4). Meanwhile, density of Miscanthus biomass harvested in autumn and chopped was as low as $0.105 \pm 0.008 \mathrm{~g} \mathrm{~cm}^{3}$, and DM density was more than three times lower than that of the biomass prepared in Germany. The density of chopped and dried biomass was thrice as low as that of the material prepared in Germany. Miscanthus that was harvested in autumn, chopped, dried and milled had density and DM amount similar to that of the biomass prepared in Germany, $0.194 \pm 0.013$ and $0.177 \pm 0.013 \mathrm{~g}$ $\mathrm{cm}^{-3}$, respectively. Density of biomass harvested in spring and chopped was similar to that of biomass harvested in autumn and chopped.

Table 4. Physico-mechanical properties of Miscanthus biomass for synthetic diesel fuel production depending on biomass preparation method

\begin{tabular}{ccccc}
\hline Treatment & $\begin{array}{c}\text { Chaff mass (g) } \\
\text { in 500 ml vessel }\end{array}$ & $\begin{array}{c}\text { Dry matter }(\mathrm{g}) \\
\text { of chaff mass } \\
\text { in 500 ml vessel }\end{array}$ & $\begin{array}{c}\text { Chaff } \\
\text { bulk density } \\
\mathrm{g} \mathrm{cm}^{-3}\end{array}$ & $\begin{array}{c}\text { Bulk density } \\
\text { of chaff dry matter } \\
\mathrm{g} \mathrm{cm}^{-3}\end{array}$ \\
\hline 1 & $91.96 \pm 9.31$ & $81.88 \pm 9.31$ & $0.184 \pm 0.016$ & $0.164 \pm 0.016$ \\
2 & $52.58 \pm 4.82$ & $25.27 \pm 4.82$ & $0.105 \pm 0.008$ & $0.051 \pm 0.008$ \\
3 & $29.46 \pm 3.68$ & $26.93 \pm 3.68$ & $0.059 \pm 0.006$ & $0.054 \pm 0.006$ \\
4 & $97.04 \pm 7.36$ & $88.70 \pm 7.36$ & $0.194 \pm 0.013$ & $0.177 \pm 0.013$ \\
5 & $45.14 \pm 5.73$ & $31.51 \pm 5.73$ & $0.090 \pm 0.011$ & $0.063 \pm 0.011$ \\
\hline
\end{tabular}

Fineness (fractional composition) varied considerably depending on the biomass preparation for synthetic diesel fuel production method (Table 5). The greatest amount of the particles larger than $2 \mathrm{~mm}$ were in the treatment where Miscanthus biomass was harvested in autumn, chopped and dried. Small difference of biomass fineness was between Miscanthus biomass harvested in autumn and chopped and biomass harvested in spring and chopped. Particles larger than $2 \mathrm{~mm}$ accounted for only $2.69 \pm 0.91 \%$ in the biomass prepared in Germany ( $1^{\text {st }}$ treatment); however, similar result was achieved in Lithuania, only when biomass was harvested in autumn, chopped, dried up and milled using a miller "Retsch SM 200 " (4 $4^{\text {th }}$ treatment $)$. In German feedstock dust accounted for $38.4 \pm 7.11 \%$, in Lithuanian feedstock dust content was almost three times as low $-14.01 \pm 1.38 \%$ in the treatment where biomass was harvested in autumn, chopped, dried and milled. In other treatments there was almost no dust at all.

It is difficult to explain the significance of milling quality and particle size to the synthetic fuel production, quality or characteristics. Milling quality can be compared by the evaluation of fractional composition of milled biomass. Research evidence suggests that plant mass should be milled into particles smaller than 2-3 $\mathrm{mm}, 5 \mathrm{~mm}$ and bigger particles should make up not more than $5 \%$ and dust (smaller than $0.3 \mathrm{~mm}$ particles) should make up not more than 10-15\% (Cheng, Timilsina, 2011; Yousuf, 2012). Our study showed too high content of dust $(38.4 \%)$ in the feedstock from Germany, in Lithuanian samples dust content did not exceed the requirements and was below $15 \%$. 
Table 5. Influence of biomass preparation method on fineness (mill fractional composition) of biomass

\begin{tabular}{ccccccc}
\hline \multirow{2}{*}{ Treatment } & \multicolumn{5}{c}{ Fractional composition g and \% } \\
\cline { 2 - 7 } & $\varnothing 2 \mathrm{~mm}$ & $\varnothing 1.25 \mathrm{~mm}$ & $\varnothing 1 \mathrm{~mm}$ & $\varnothing 0.5 \mathrm{~mm}$ & $\varnothing 0.3 \mathrm{~mm}$ & dust \\
\hline \multirow{2}{*}{1} & $1.62 \pm 0.54 \mathrm{~g}$ & $0.35 \pm 0.13 \mathrm{~g}$ & $1.48 \pm 0.94 \mathrm{~g}$ & $19.55 \pm 4.38 \mathrm{~g}$ & $13.97 \pm 1.44 \mathrm{~g}$ & $23.03 \pm 4.30 \mathrm{~g}$ \\
& $2.69 \pm 0.91 \%$ & $0.59 \pm 0.29 \%$ & $2.46 \pm 0.71 \%$ & $32.6 \pm 7.32 \%$ & $23.3 \pm 2.31 \%$ & $38.4 \pm 7.11 \%$ \\
\hline \multirow{2}{*}{2} & $58.5 \pm 1.43 \mathrm{~g}$ & $0.60 \pm 0.15 \mathrm{~g}$ & $0.34 \pm 0.14 \mathrm{~g}$ & $0.47 \pm 0.11 \mathrm{~g}$ & $0.05 \pm 0.01 \mathrm{~g}$ & $0.02 \pm 0.01 \mathrm{~g}$ \\
& $97.5 \pm 2.39 \%$ & $1.0 \pm 0.26 \%$ & $0.57 \pm 0.08 \%$ & $0.79 \pm 0.18 \%$ & $0.08 \pm 0.02 \%$ & $0.03 \pm 0.01 \%$ \\
\hline \multirow{2}{*}{3} & $58.5 \pm 1.24 \mathrm{~g}$ & $0.38 \pm 0.17 \mathrm{~g}$ & $0.48 \pm 0.14 \mathrm{~g}$ & $0.54 \pm 0.20 \mathrm{~g}$ & $0.09 \pm 0.03 \mathrm{~g}$ & $0.03 \pm 0.02 \mathrm{~g}$ \\
& $98.2 \pm 3.17 \%$ & $0.46 \pm 0.14 \%$ & $0.47 \pm 0.07 \%$ & $0.73 \pm 0.25 \%$ & $0.14 \pm 0.05 \%$ & $0.04 \pm 0.01 \%$ \\
\hline \multirow{2}{*}{4} & $0.17 \pm 0.04 \mathrm{~g}$ & $0.88 \pm 0.32 \mathrm{~g}$ & $7.59 \pm 2.62 \mathrm{~g}$ & $31.4 \pm 7.95 \mathrm{~g}$ & $11.52 \pm 2.71 \mathrm{~g}$ & $8.41 \pm 0.83 \mathrm{~g}$ \\
& $0.28 \pm 0.08 \%$ & $1.46 \pm 0.27 \%$ & $12.65 \pm 2.71 \%$ & $52.4 \pm 13.27 \%$ & $19.21 \pm 4.51 \%$ & $14.01 \pm 1.38 \%$ \\
\hline \multirow{2}{*}{5} & $57.8 \pm 1.49 \mathrm{~g}$ & $0.79 \pm 0.03 \mathrm{~g}$ & $0.56 \pm 0.17 \mathrm{~g}$ & $0.64 \pm 0.24 \mathrm{~g}$ & $0.14 \pm 0.03 \mathrm{~g}$ & $0.04 \pm 0.01 \mathrm{~g}$ \\
& $96.4 \pm 1.04 \%$ & $1.33 \pm 0.04 \%$ & $0.95 \pm 0.29 \%$ & $1.09 \pm 0.15 \%$ & $0.23 \pm 0.08 \%$ & $0.06 \pm 0.02 \%$ \\
\hline
\end{tabular}

Energy consumption and efficiency. It was found that chopping of Miscanthus biomass harvested in autumn ( $2^{\text {nd }}$ treatment) or harvested in spring $\left(5^{\text {th }}\right.$ treatment) affected the efficiency and energy consumption of the drum chopper "Maral 125". The research data show that in spring-harvested biomass the energy used to chop Miscanthus is higher and productivity lower (Table 6). At a feeding load of $1.5 \mathrm{~kg}$ of Miscanthus biomass into the chopper, the difference in chopping efficiency between autumn and spring-harvested biomass was $4.4 \%$ and at $4.5 \mathrm{~kg}$ feeding load it was $14.7 \%$.

Table 6. Labour efficiency and energy consumption of drum chopper "Maral 125"

\begin{tabular}{|c|c|c|c|}
\hline \multicolumn{2}{|c|}{$\begin{array}{l}\text { Indicator and test conditions } \\
\text { (biomass samples fed } \\
\text { into the chopper) }\end{array}$} & \multirow{2}{*}{$\begin{array}{c}\begin{array}{c}\text { Autumn- } \\
\text { harvested } \\
\text { biomass, } \\
2^{\text {nd }} \text { treatment }\end{array} \\
0.90 \pm 0.01\end{array}$} & \multirow{2}{*}{$\begin{array}{c}\text { Spring- } \\
\text { harvested } \\
\text { biomass, } \\
5^{\text {th }} \text { treatment } \\
0.0054 \pm 0.0016\end{array}$} \\
\hline \multirow{3}{*}{ Labour efficiency $\mathrm{t} \mathrm{h}^{-1}$} & $1.5 \mathrm{~kg}$ & & \\
\hline & $3 \mathrm{~kg}$ & $1.30 \pm 0.37$ & $0.0118 \pm 0.0037$ \\
\hline & $4.5 \mathrm{~kg}$ & $1.97 \pm 0.62$ & $0.0166 \pm 0.0044$ \\
\hline \multirow{3}{*}{$\begin{array}{l}\text { Difference in labour } \\
\text { efficiency between } \\
5^{\text {th }} \text { and } 2^{\text {nd }} \text { treatments } \%\end{array}$} & $1.5 \mathrm{~kg}$ & - & -4.4 \\
\hline & $3 \mathrm{~kg}$ & - & -3.9 \\
\hline & $4.5 \mathrm{~kg}$ & - & -14.7 \\
\hline \multirow{3}{*}{$\begin{array}{l}\text { Energy consumption } \\
\mathrm{kWh}\end{array}$} & $15 \mathrm{~kg}$ & $0.86 \pm 0.32$ & $0.0071 \pm 0.0026$ \\
\hline & $3 \mathrm{~kg}$ & $1.25 \pm 0.37$ & $0.0134 \pm 0.0020$ \\
\hline & $4.5 \mathrm{~kg}$ & $1.68 \pm 0.45$ & $0.0228 \pm 0.0089$ \\
\hline \multirow{3}{*}{$\begin{array}{l}\text { Difference in energy } \\
\text { consumption between } \\
5^{\text {th }} \text { and } 2^{\text {nd }} \text { treatments } \%\end{array}$} & $1.5 \mathrm{~kg}$ & - & +31.5 \\
\hline & $3 \mathrm{~kg}$ & - & +13.6 \\
\hline & $4.5 \mathrm{~kg}$ & - & +37.4 \\
\hline
\end{tabular}

Energy consumption for chopping of Miscanthus biomass harvested in spring ( $5^{\text {th }}$ treatment) at $1.5 \mathrm{~kg}$ of feeding load was $31.5 \%$ greater and $37.4 \%$ greater at 4.5 $\mathrm{kg}$ feeding load compared with the biomass harvested in autumn ( $2^{\text {nd }}$ treatment). We found that increasing sample weight from 1.5 to $4.5 \mathrm{~kg}$, or three-fold, energy consumption used to chop it is increased by more than three times. It was found that the weight of chopped and dried Miscanthus biomass samples had an impact on the mill's efficiency and energy consumption (Table 7).
When the mass of the Miscanthus supplied to the mill is increased from 25 to $75 \mathrm{~g}$, the energy consumption used to mill it increased approximately twice and efficiency of the mill more than three times.

Table 7. Mill "Retsch SM 200" efficiency and energy consumption for milling of Miscanthus biomass

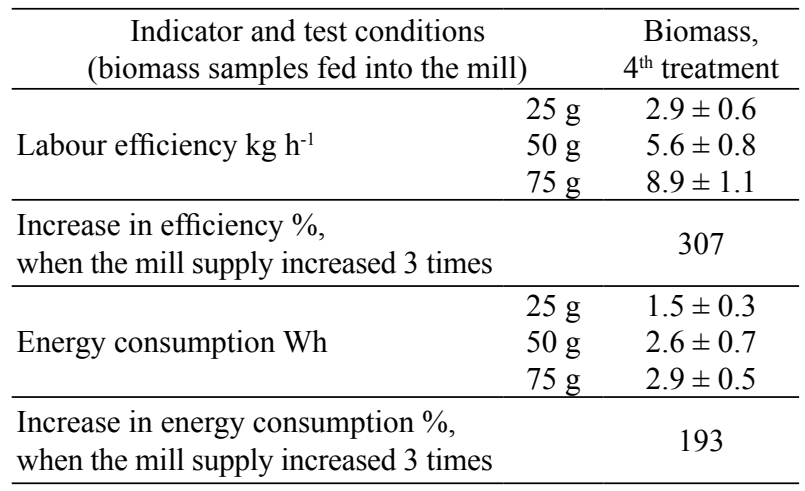

Evaluation of possibilities of Miscanthus biomass use for production of diesel fuel. Aiming to determine the possibilities to utilise the dried and properly prepared Miscanthus biomass for diesel fuel production as well as to determine the properties of synthesised fuel, biomass prepared in Germany was supplied as feedstock for the process of biomass liquefaction (liquid hydrocarbons production) by applying the CPD process. First trials were made seeking to prove that Miscanthus biomass could be effectively transformed into biofuel which meets the standard requirements and could be used in diesel engines. Test results of physical and chemical properties of liquid product produced from the Miscanthus biomass prepared in Germany and the requirements of standards for mineral diesel fuel LST EN 590 and standards for biodiesel LST EN 14214 are provided in Table 8 .

For a more complex comparison of the composition of synthetic diesel fuel produced from Miscantus biomass with that of fossil diesel fuel, a Fourier transformation infrared spectroscopic analysis of both products was performed. The results are shown in Figure 2. 
Table 8. Physical and chemical parameters of synthetic fuel and their compliance with the requirements of LST EN 590 and LST EN 14214 standards

\begin{tabular}{|c|c|c|c|c|c|}
\hline \multirow{2}{*}{ Parameter } & \multicolumn{2}{|c|}{ Requirements of LST EN 590} & \multicolumn{2}{|c|}{ Requirements of LST EN 14214} & \multirow{2}{*}{$\begin{array}{l}\text { Determined } \\
\text { value }\end{array}$} \\
\hline & $\min$. & $\max$. & $\min$. & $\max$. & \\
\hline Density at $15^{\circ} \mathrm{C} \mathrm{kg} \mathrm{m}^{-3}$ & 820 & 845 & 860 & 900 & 830 \\
\hline Viscosity at $40^{\circ} \mathrm{C} \mathrm{mm}^{2} \mathrm{~s}^{-1}$ & 2.00 & 4.50 & 3.5 & 5.0 & 2.2 \\
\hline Acid value mg KOH g$~^{-1}$ & - & - & - & 0.5 & 0.53 \\
\hline Iodine value $\mathrm{g} \mathrm{J}_{2} 100 \mathrm{~g}^{-1}$ & - & - & - & 120 & 19.2 \\
\hline Sulphur content $\mathrm{mg} \mathrm{kg}^{-1}$ & - & 10 & - & 10 & 98 \\
\hline Water content $\mathrm{mg} \mathrm{kg}^{-1}$ & - & 200 & - & 500 & 120 \\
\hline Flashpoint ${ }^{\circ} \mathrm{C}$ & $\sim 55$ & - & 120 & - & 61 \\
\hline Ignition temperature ${ }^{\circ} \mathrm{C}$ & - & - & - & - & 64 \\
\hline Pour point ${ }^{\circ} \mathrm{C}$ & - & $-22(\operatorname{arctic}$ class 4$)$ & - & - & -24 \\
\hline Cold filter plugging point ${ }^{\circ} \mathrm{C}$ & - & $-44(\operatorname{arctic}$ class 4$)$ & - & $-44(\operatorname{arctic}$ class 4$)$ & $<-45$ \\
\hline
\end{tabular}

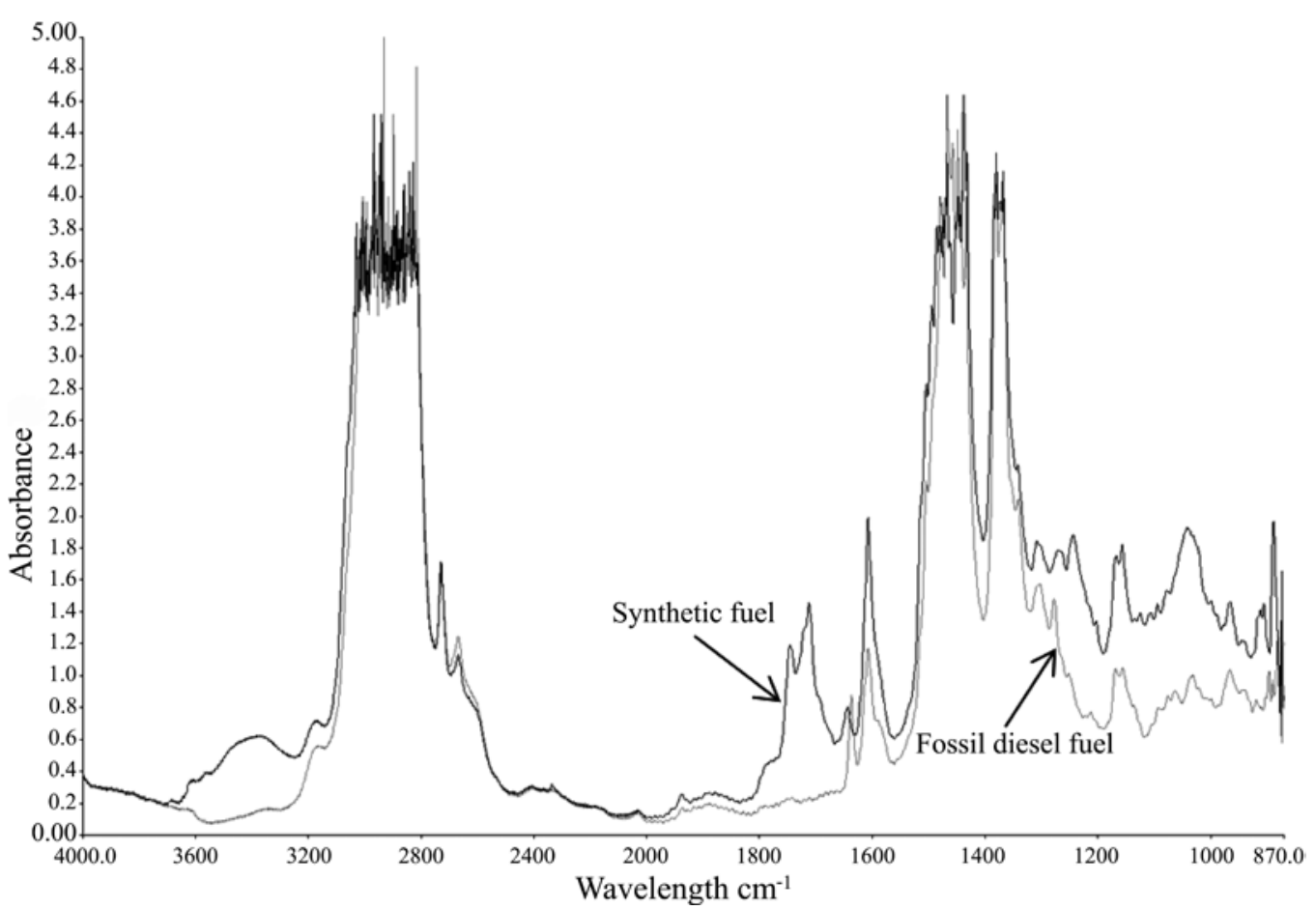

Figure 2. Fourier transformation infrared (FTIR) spectroscopy analysis of spectra of synthetic and fossil diesel fuel

Summarizing the results we can state that synthetic fuel is similar to fossil diesel fuel and meets the requirements of standard LST EN 590 for mineral diesel in respect to the properties that were analyzed. Synthetic fuel is flammable: flash point and ignition temperature are relatively low. The new fuel is characterised by very good low-temperature properties which are better than those of the arctic class 4 mineral diesel. Acidity of synthetic fuel is slightly above the maximum value specified in the biodiesel standard LST EN 14214; this indicates that fuel contains carboxylic acids, which can cause engine corrosion. Iodine value shows that the synthetic fuel contains a small amount (5-7\%) of unsaturated hydrocarbons, as confirmed by the FTIR spectrum (3020-3080 $\mathrm{cm}^{-1}$ absorption area). Comparative spectral analysis demonstrates that in terms of composition, synthetic fuel is very similar to mineral diesel. Only a few parts of the spectrum have specific absorption areas not observed in the spectrum of fossil diesel fuel. Absorption area of $1600-1800 \mathrm{~cm}^{-1}$ indicates that the product may contain aldehydes, ketones and carboxylic acids, and their presence is confirmed by acidity measurements.

Our first experiments on fuel synthesis from Miscanthus biomass and analysis of fuel properties proved that Miscanthus biomass could be effectively used for synthetic fuel production. Further experiments need to be performed for the evaluation of the influence of biomass preparation methods and quality of prepared Miscanthus biomass on quantitative and qualitative parameters of synthetic fuel. It is necessary aiming to optimise the CPD process and to select the most effective biomass preparation methods for the production of synthetic fuel with the highest quality. In order to use such fuel in the transport sector, it is also necessary to carry out detailed tests on diesel engine operation and to analyse harmful components in the engine emissions. 


\section{Conclusions}

1. Miscanthus can be expected to produce a promising biomass yield for growing for bioenergy purposes in Lithuania. Nitrogen fertilizer increased biomass yield of Miscanthus; however, delaying harvest until spring resulted in significant dry matter yield losses. Harvesting timing can be an important tool to ensure suitable biomass composition for conversion process and efficient production of energy.

2. Miscanthus harvesting time affects physicomechanical properties of the biomass prepared for synthetic diesel production, machine use efficiency and energy consumption. The energy use for autumn-harvested biomass chopping was lower and the chopper efficiency was higher compared with spring- harvested biomass.

3. While preparing biomass as feedstock for synthetic diesel the greatest reduction in moisture content (to $8.59 \pm 1.38 \%$ ) occurred when Miscanthus biomass was chopped, pre-dried and milled, and particles larger than $2 \mathrm{~mm}$ accounted for the largest share.

4. Chemical assays and Fourier transformation infrared spectroscopic analysis were performed to compare in a more complex way the composition of liquid synthetic fuel produced from Miscantus biomass with that of fossil diesel fuel. The results of analyses demonstrate that in terms of composition, synthetic fuel is very similar to fossil diesel fuel.

\section{Acknowledgements}

This work was part of the ESF project "Scientific validation of $\mathrm{C} 3$ and $\mathrm{C} 4$ herbaceous plants' multifunctionality for innovative technologies: phyto-raw materials - bio-products - environmental effects" (VP13.1-MM-08-K-01-023).

Received 06032013

Accepted 26022014

\section{References}

Anderson E., Arundale R., Maughan M., Oladeinde A., Wycislo A., Voigt T. 2011. Growth and agronomy of Miscanthus $\times$ giganteus for biomass production. Biofuels, 2 (2): 167-183 http://dx.doi.org/10.4155/bfs. 10.80

Carriquiry M.A., Du X., Timilsina G. R. 2011. Second generation biofuels: economics and policies. Energy Policy, 39: 4222 4234 http://dx.doi.org/10.1016/j.enpol.2011.04.036

Cheng J. J., Timilsina G. R. 2011. Status and barriers of advanced biofuel technologies: a review. Renewable Energy, 36: 3541-3549

http://dx.doi.org/10.1016/j.renene.2011.04.031

Clifton-Brown J. C., Lewandowski I. 2002. Screening Miscanthus genotypes in field trials to optimise biomass yield and quality in southern Germany. European Journal of Agronomy, 16: 97-100 http://dx.doi.org/10.1016/S1161-0301(01)00120-4

Clifton-Brown J. C., Stampfil P. F., Jones M. B. 2004. Miscanthus biomass production for energy in Europe and its potential contribution to decreasing fossil fuel carbon emissions. Global Change Biology, 10 (4): 509-518 http://dx.doi.org/10.1111/j.1529-8817.2003.00749.x

Demirbas A. 2009. Biorefineries: current activities and future developments. Energy Conversion and Management, 50: 2782-2801

http://dx.doi.org/10.1016/j.enconman.2009.06.035
Faithfull N. T. 2002. Methods in agricultural chemical analysis: a practical handbook. Wallingford, USA, $266 \mathrm{p}$.

Hastings A., Clifton-Brown J., Wattenbach M., Mitchell C. P., Stampfl P., Smith P. 2009. Future energy potential of Miscanthus in Europe. GCB Bioenergy, 1: 180-196 http://dx.doi.org/10.1111/j.1757-1707.2009.01012.x

Hindrichsen I. K., Kreuzer M., Madsen J., Bach Knudsen K. E. 2006. Fiber and lignin analysis in concentrate, forage, and feces: detergent versus enzymatic-chemical method. Journal of Dairy Science, 89 (6): 2168-2176 http://dx.doi.org/10.3168/jds.S0022-0302(06)72287-1

Hodgson E. M., Nowakowski D. J., Shield I., Riche A., Bridgwater A. V., Clifton-Brown J. C., Donnison I. S. 2011. Variation in Miscanthus chemical composition and implications for conversion by pyrolysis and thermochemical bio-refining for fuels and chemicals. Bioresource Technology, 102: 3411-3418 http://dx.doi.org/10.1016/j.biortech.2010.10.017

Huyen T. L., Rémond C., Dheilly R. M., Chabbert B. 2010. Effect of harvesting date on the composition and saccharification of Miscanthus $\times$ giganteus. Bioresource Technology, 101: 8224-8231 http://dx.doi.org/10.1016/j.biortech.2010.05.087

Igathinathane C., Womac A. R., Sokhansanj S., Narayan S. 2008. Knife grid size reduction to preprocess packed beds of high- and low-moisture switchgrass. Bioresource Technology, 99: 2254-2264 http://dx.doi.org/10.1016/j.biortech.2007.05.046

Janaun J., Ellis N. 2010. Perspectives on biodiesel as a sustainable fuel. Renewable and Sustainable Energy Reviews, 14: 1312-1320 http://dx.doi.org/10.1016/j.rser.2009.12.011

Jasinskas A., Zvicevičius E. 2008. Engineering of biomass production: instructionalbookforhigherschools.Lithuanian University of Agriculture, 98 p. (in Lithuanian)

Jasinskas A., Ulozevičiūte I., Rutkauskas G. 2012. Plant biomass production and use as an environmentally-friendly local fuel. Polish Journal of Environmental Studies, 21 (1): 89-94

Jezowski S., Glowacka K., Kaczmarek Z. 2011. Variation on biomass yield and morphological traits of energy grasses from the genus Miscanthus during the first years of crop establishment. Biomass and Bioenergy, 35: 814-821 http://dx.doi.org/10.1016/j.biombioe.2010.11.013

Johnson P. C., Clementson C. L., Mathanker S. K., Grift T. E., Hansen A. C. 2012. Cutting energy characteristics of Miscanthus $\times$ giganteus stems with varying oblique angle and cutting speed. Biosystems Engineering, 112: 42-48 http://dx.doi.org/10.1016/j.biosystemseng.2012.02.003

Kaack K., Schwarz K. U. 2001. Morphological and mechanical properties of Miscanthus in relation to harvesting, lodging, and growth conditions. Industrial Crops and Products, 14 (2): $145-154$ http://dx.doi.org/10.1016/S0926-6690(01)00078-4

Kaack K., Schwarz K. U., Brande P. E. 2003. Variation in morphology, anatomy and chemistry of stems of Miscanthus genotypes differing in mechanical properties. Industrial Crops and Products, 17: 131-142 http://dx.doi.org/10.1016/S0926-6690(02)00093-6

Kryževičienė A., Kadžiulienė Ž., Šarūnaitè L., Dabkevičius Z., Tilvikiene V., Šlepetys J. 2011. Cultivation of Miscanthus $\times$ giganteus for biofuel and its tolerance of Lithuania's climate. Zemdirbyste-Agriculture, 98 (3): 267-274

Lewandowski I., Heinz A. 2003. Delayed harvest of Miscanthus - influences on biomass quantity and quality and environmental impacts of energy production. European Journal of Agronomy, 19: 45-63 http://dx.doi.org/10.1016/S1161-0301(02)00018-7 
Lewandowski I., Kauter D. 2003. The influence of nitrogen fertilizer on the yield and combustion quality of whole grain crops for solid fuel use. Industrial Crops and Products, 17: 103-117

http://dx.doi.org/10.1016/S0926-6690(02)00090-0

Mani S., Tabil L. G., Sokhansanj S. 2006. Effects of compressive force, particle size and moisture content on mechanical properties of biomass pellets from grasses. Biomass and Bioenergy, 30: 648-654 http://dx.doi.org/10.1016/j.biombioe.2005.01.004

Reijnders L. 2010. Transport biofuel yields from food and lignocellulosic C4 crops. Biomass and Bioenergy, 34: $152-155$ http://dx.doi.org/10.1016/j.biombioe.2009.10.004

Robbins M. P., Evans G., Valentine J., Donnison I. S., Allison G. G. 2012. New opportunities for the exploitation of energy crops by thermochemical conversion in Northern Europe and the UK. Progress in Energy and Combustion Science, 38: 138-155 http://dx.doi.org/10.1016/j.pecs.2011.08.001
Robson P., Mos M., Clifton-Brown J., Donnison I. 2012. Phenotypic variation in senescence in Miscanthus: towards optimising biomass quality and quantity. BioEnergy Research, 5 (1): 95-105 http://dx.doi.org/10.1007/s12155-011-9118-6

Yousuf A. 2012. Biodiesel from lignocellulosic biomass prospects and challenges. Waste Management, 32: 20612067 http://dx.doi.org/10.1016/j.wasman.2012.03.008

Simmons B. A. 2012. Bioenergy from plants and plant residues. Altman A., Hasegawa P. M. (eds). Plant Biotechnology and Agriculture, p. 495-505

Tarakanovas P., Raudonius S. 2003. Agronominių tyrimų duomenų statistinè analizè taikant kompiuterines programas ANOVA, STAT, SPLIT-PLOT iš paketo SELEKCIJA ir IRRISTAT. Lithuanian University of Agriculture, $58 \mathrm{p}$. (in Lithuanian)

Zub H. W., Arnoult S., Brancourt-Hulmel M. 2011. Key traits for biomass production identified in different Miscanthus species at two harvest dates. Biomass and Bioenergy, 35: $637-651$

http://dx.doi.org/10.1016/j.biombioe.2010.10.020

ISSN 1392-3196 / e-ISSN 2335-8947

Zemdirbyste-Agriculture, vol. 101, No. 1 (2014), p. 27-34

DOI $10.13080 /$ z-a.2014.101.004

\title{
Miskantų biomasės kokybinè sudètis ir žaliavos paruošimo konversijai ị sintetinị dyzeliną metodai
}

\author{
Ž. Kadžiulienė ${ }^{1}$, A. Jasinskas², R. Zinkevičius², V. Makarevičiené ${ }^{3}$, \\ L. Šarūnaite $\dot{1}^{1}$, V. Tilvikiené $\dot{e}^{1}$, J. Šlepetys ${ }^{1}$ \\ ${ }^{1}$ Lietuvos agrarinių ir miškų mokslų centro Žemdirbystės institutas \\ ${ }^{2}$ Aleksandro Stulginskio universiteto Žemès ūkio inžinerijos ir saugos institutas \\ ${ }^{3}$ Aleksandro Stulginskio universiteto Aplinkos ir ekologijos institutas
}

\section{Santrauka}

Plètojant ịvairias biomasès konvertavimo ị biodegalus technologijas, yra svarbu nustatyti žaliavos tinkamumą tokių celiuliozinių augalų kaip miskantai, kurių biomasè turi gerą energini potencialą ir jie nèra mitybiniai augalai. Didelès reikšmès turi tokių mažiau tyrinètų ir rečiau auginamų augalų biomasės produktyvumas, kokybė ir jos tinkamumas perdirbti šiauresnio klimato sąlygomis. Eksperimentai atlikti siekiant ịvertinti miskantų auginimo, derliaus nuemimo ir perdirbimo ị sintetinį dyzeliną kokybinius bei technologinius rodiklius, chemines, fizines bei mechanines biomasès savybes ir nustatyti energijos sunaudojimo kiekį, reikalingą biomasę ruošiant perdirbti ị sintetinị dyzeliną. Objektas - miskantų (Miscanthus $\times$ giganteus Greef et Deu), užaugintų Lietuvos klimato zonoje (analizuota išsamiau), ir miskantu, užaugintu Vokietijos klimato zonoje, biomasè. Gautas iki 9,42 $\mathrm{t} \mathrm{ha}^{-1}$ miskantų sausuju medžiagu (s. m.) rudeninis derlius, ir jie buvo esmingai derlingesni patręšus didesne norma azoto. Celiuliozès $\left(413-456 \mathrm{~g} \mathrm{~kg}^{-1} \mathrm{~s}\right.$. m.) ir hemiceliuliozès (204-236 g kg-1 s. m.) kiekiai buvo labai panašūs esant visiems tręšimo lygiams, o didžiausias kiekis lignino nustatytas biomasėje, kai tręšta $120 \mathrm{~kg} \mathrm{ha}^{-1} \mathrm{~N}-117 \mathrm{~g} \mathrm{~kg}^{-1} \mathrm{~s}$. m. Pavasarị miskantų biomasèje buvo žymiai mažesnis kiekis drègmès, bet derlius taip pat buvo gerokai mažesnis. Biomasę ruošiant kaip žaliavą sintetiniam dyzelinui, drègnumas labiausiai sumažèjo (iki 8,59 $\pm 1,38 \%$ ), kai miskantų biomasė buvo susmulkinta, iš anksto išdžiovinta bei sumalta ir buvo daugiausia didesnių nei $2 \mathrm{~mm}$ dalelių. Kapojant rudenị nuimtą biomasę energijos sunaudojimas buvo mažesnis, o kapojimo proceso efektyvumas buvo didesnis, palyginti su biomasės, nuimtos ankstyvą pavasarị, apdorojimu. Nustatyta, kad sintetinio kuro iš miskantų biomasès pagrindinių komponentų sudètis yra labai panaši ị mineralinio dyzelino.

Reikšminiai žodžiai: biomasè, fizinès ir mechaninès savybès, miskantai, nuėmimo laikas, sintetinis dyzelinas. 